\title{
WYKAZ PRAC DYPLOMOWYCH Z ANTYKU CHRZEŚCIJAŃSKIEGO UKOŃCZONYCH W NIEKTÓRYCH POLSKICH OŚRODKACH NAUKOWYCH W 2007-2008 ROKU
}

\section{KATOLICKI UNIWERSYTET LUBELSKI JANA PAWLA II}

\section{A. WYDZIAŁ TEOLOGII}

\section{Prace habilitacyjne}

1. Leśniewski Krzysztof, „Nie potrzebują lekarza zdrowi”. Hezychastyczna metoda uzdrawiania człowieka, Lublin 2007. Kolokwium 19 VI 2007, recenzenci: ks. prof. dr hab. J. Popławski (KUL), abp Jeremiasz J. Anchimiuk (ChAT), ks. prof. dr hab. J. Jaskuła (UO), ks. prof. dr hab. Z. Kijas (PAT).

2. Ks. Szczur Piotr, Problematyka społeczna w późnoantycznej Antiochii na podstawie nauczania homiletycznego Jana Chryzostoma, Lublin 2008. Kolokwium 27 VI 2008, recenzenci: ks. prof. dr hab. M. Szram (KUL), ks. prof. dr hab. B. Częsz (UAM), ks. prof. dr hab. J. Naumowicz (UKSW), ks. prof. dr hab. A. Żurek (PAT).

3. Ks. Zagórski Dariusz, Model doskonalenia chrześcijańskiego w świetle ekshortacji pastoralnych św. Grzegorza z Nazjanzu, Toruń 2008. Kolokwium 22 IV 2008, recenzenci: ks. prof. dr hab. F. Drączkowski (KUL), ks. prof. dr hab. Bogdan Częsz (UAM), ks. prof. dr hab. Wincenty Myszor (UŚ), ks. prof. dr hab. H. Pietras (WSFP Ignatianum)

$$
\text { Prace doktorskie }
$$

1. O. Aleksiychuk Valery, Przełożony jako ojcie duchowny. Studium na podstawie życia i nauczania św. Teodora Studyty. Promotor: ks. prof. dr hab. J. Misiurek (KUL), obrona 18 IV 2008, recenzenci: ks. prof. dr hab. J. Maskałyk (UAM) i ks. prof. dr hab. J. Popławski (KUL).

2. Ks. Buliński Roman, Program pracy duszpasterskiej papieża Grzegorza Wielkiego $w$ świetle ekshortacji pastoralnych zawartych $w$,,XL Homiliarum in Evangelia”. Promotor: ks. prof. dr hab. R. Kamiński, obrona 24 I 2008, recenzenci: ks. prof. dr hab. B. Mierzwiński (UKSW) i ks. prof. dr hab. F. Drączkowski (KUL).

3. Ks. Duda Jerzy, ,,Jeden świat czy wiele światów”. Kosmologiczne podstawy doktryny Orygenesa. Promotor: ks. prof. dr hab. M. Szram (KUL), obrona 24 IV 2007, recenzenci: ks. prof. dr hab. A. Żurek (PAT) i ks. prof. dr hab. F. Drączkowski (KUL). 
4. Stawowy Magdalena P., Wokót postaci św. Mikołaja - pieśni, modlitwy, muzyka. Z badań nad Tradycja Kościołów chrześcijańskich w Polsce: łaciński, prawostawny, unicki. Promotor: prof. dr hab. A. Czekanowska-Kuklińska (KUL), obrona 6 XII 2007, recenzenci: prof. dr hab. B. Muszkalska (UWr) i prof. dr hab. A. Zoła (KUL).

5. Ks. Strankowski Marian, Przepowiadanie Stowa Bożego w ,Enarrationes in Psalmos" św. Augustyna. Promotor: ks. prof. dr hab. J. Pałucki (KUL), obrona 19 VI 2008, recenzenci: prof. dr hab. J. Wojtczak-Szyszkowski (UW) i ks. prof. dr hab. F. Drączkowski (KUL).

6. Ks. Szczerba Czesław, Hermeneutyka teologiczna Grzegorza Wielkiego na podstawie „Homilii na Ewangelie”. Promotor: ks. prof. dr hab. K. Guzowski (KUL), obrona 10 VI 2008, recenzenci: ks. prof. dr hab. B. Gacka (UKSW) i ks. prof. dr hab. J. Szymik (UŚ).

7. Ks. Wysocki Marcin, Eschatologia okresu prześladowań na podstawie pism Tertuliana i Cypriana. Promotor: ks. prof. dr hab. M. Szram (KUL), obrona 19 VI 2008, recenzenci: prof. dr hab. J. Wojtczak-Szyszkowski (UW) i ks. prof. dr hab. J. Pałucki (KUL).

Prace licencjackie

1. Bylińska Magdalena, Rola cnót w procesie doskonalenia życia chrześcijańskiego w świetle „In Joannis Evangelium tractatus CXXIV” $i$,In epistolam Joannis in Parthos tractatus decem" s'w. Augustyna (prom. ks. prof. dr hab. J. Pałucki, 2008).

2. Ks. Czajkowski Krzysztof, Symbolika zwierzat wedtug Enarrationes in Psalmos św. Augustyna (I-LXXV) (prom. ks. prof. dr hab. J. F. Drączkowski, 2008).

3. Czendlik Joanna, Obraz nieba w listach św. Hieronima (prom. ks. prof. dr hab. M. Szram, 2007).

4. Ks. Ćwiek Przemysław, @eó w filozofii starożytnej Grecji. Od presokratyków do Platona (prom. ks. prof. dr hab. J. Sochon, 2007).

5. Ks. Górski Szymon, Przełożony i istota jego urzędu na podstawie tekstów starożytnych reguł monastycznych Kościoła Zachodniego (prom. bp dr K. Gurda, 2008).

6. Ks. Jankowski Andrzej, Św. Wawrzyniec w tacińskiej literaturze wczesnochrześcijańskiej (prom. ks. dr hab. T. Gacia, 2008).

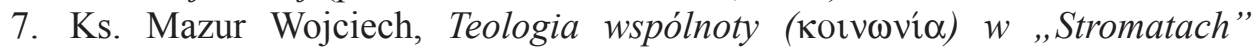
Klemensa Aleksandryjskiego (prom. ks. prof. dr hab. M. Szram, 2008).

8. Ks. Pagór Jarosław, Koncepcja wcielenia Logosu wedlug św. Atanazego Wielkiego (prom. bp. prof. dr hab. metropolita Sawa [M. Hrycuniak], 2008).

9. Ks. Rosochacki Adam, Motywy agonistyczne i ich funkcja w pismach Tertuliana (prom. ks. prof. dr hab. T. Gacia, 2007).

10. Ks. Szewczyk Przemysław, Nauczanie o Eucharystii $w$ komentarzach św. Augustyna do VI rozdzialu Ewangelii św. Jana (prom. ks. prof. dr hab. J. Słomka, 2007). 


\section{Prace magisterskie}

1. Binienda Monika, Poczęcie ciąża i urodzenie dziecka w nauce ginekologa Soranosa i chrześcijańskiego apologety Tertuliana (prom. ks. prof. dr hab. S. Longosz, 2008).

2. Bulińska Aleksandra, Dziecko i jego wychowanie w pismach św. Jana Chryzostoma (prom. ks. prof. dr hab. S. Longosz, 2007).

3. Dobrzańska Magdalena, Dziewictwo i jego pielegnowanie w „Listach” św. Hieronima (prom. ks. prof. dr hab. S. Longosz, 2007).

4. Dzyr Szczepan, Rola cnoty postuszeństwa $w$ walce $z$ szatanem na podstawie Apoftegmatów Ojców Pustyni (prom. ks. prof. dr hab. M. Szram, 2008).

5. Karwasz Jacek, Program doskonalenia chrześsijańskiego $w$ świetle patrystycznych exhortacji pastoralnych wystepujacych w Liturgii Godzin (tom III) (prom. ks. prof. dr hab. F. Drączkowski, 2008).

6. Klępka Paweł, Jana Chryzostoma nauka o postach w świetle jego „Homilii na Ewangelię wedlug św. Mateusza” (prom. ks. prof. dr hab. F. Drączkowski, 2008).

7. Kozicka Monika, Kobieta $i$ jej zadania $w$ wybranych pismach Św. Jana Chryzostoma (prom. ks. prof. dr hab. S. Longosz, 2008).

8. Król Anna, Godność kobiety na podstawie „Mulieris dignitatem” Jana Pawła II i jej uzasadnienie biblijno-patrystyczne (prom. ks. prof. dr hab. S. Longosz, 2007).

9. Lis Michał, Mężczyzna i jego zadania w listach świętego Hieronima (prom. ks. prof. dr hab. S. Longosz, 2008).

10. Litwin Daniel, Święty Józef jako wzór męża i ojca w Apokryfach Nowego Testamentu (prom. ks. prof. dr hab. S. Longosz, 2008).

11. Łesyk Lesław, Kapłan - formacja i postuga w nauczaniu św. Jana Chryzostoma na podstawie „Dialogu o kaptaństwie” (prom. ks. prof. dr hab. J. Pałucki, 2007).

12. Malinowski Radosław, Męczeństwo w świetle dziet św. Cypriana i Tertuliana (prom. ks. prof. dr hab. J. Pałucki, 2008).

13. Marchewka Joanna, Ideat życia chrześcijańskiego w tworzeniu cywilizacji mitości w świetle „De sermone Domini in monte libri duo” świętego Augustyna (prom. ks. prof. dr hab. J. Pałucki, 2007).

14. Miszczuk Dorota, Kobieta jako świadek wiary w wybranych aktach męczeńskich (prom. ks. prof. dr hab. S. Longosz, 2008).

15. Motowidło Stanisław, Eklezjologia św. Augustyna w świetle "Enarrationes in Psalmos" (prom. ks. prof. dr hab. J. Pałucki, 2008).

16. Niewęgłowski Remigiusz, Dawid jako exemplum w ,,De apologia prophetae David” świętego Ambrożego (prom. ks. prof. dr hab. J. Pałucki, 2008).

17. Parczyńska Anna K., Rodzina „Kościołem domowym” w nauczaniu Jana Pawta II (prom. ks. prof. dr hab. S. Longosz, 2007).

18. Parczyński Wojciech, Nierozerwalność małzeństwa wnauczaniuśw. Augustyna i papieża Piusa XI (prom. ks. prof. dr hab. S. Longosz, 2007).

19. Piskorz Tomasz, Nauka o grzechu wedtug „Enarrationes in Psalmos” św. Augustyna (prom. ks. prof. dr hab. J. Pałucki, 2008).

20. Podgórski Wojciech, Szymon Mag (Dz 8, 5-25) i recepcja jego postaci w literaturze pozabiblijnej (prom. ks. prof. dr hab. S.H. Szymik, 2008). 
21. O. Romanek Jacek, Koncepcja świętości chrześcijanina na podstawie homilii Orygenesa do Pentateuchu (prom. ks. prof. dr hab. M. Szram, 2007).

22. Siteń Izabela, Wierność matżeńska w pismach świętego Augustyna (prom. ks. prof. dr hab. S. Longosz, 2008).

23. Szczeblewski Dawid, Program doskonalenia chrześcijańskiego w świetle patrystycznych exhortacji występujacych w Liturgii Godzin (Tom 1) (prom. ks. prof. dr hab. F. Drączkowski, 2008).

24. Szejgiec Ewelina, Demonologia w Enarrationes in Psalmos św. Augustyna (prom. ks. prof. dr hab. J. Pałucki, 2007).

25. Smierzchalski Paweł, Elementy rodzinne w kulcie Świętego Mikołaja z Myry (prom. ks. prof. dr hab. S. Longosz, 2007).

26. Wolan Piotr, Chrystologia świętego Grzegorza Wielkiego w świetle „Homilii na Ewangelie" (prom. ks. prof. dr hab. J. Pałucki, 2008).

27. Wójcik Krzysztof, Zarzuty kierowane pod adresem chrześcijan i ich odparcie w świetle Apologii świętego Justyna (prom. ks. prof. dr hab. F. Drączkowski, 2008).

28. Wyrozębska Ewelina, Opieka nad sierotami w starożytności pogańskiej i chrześcijańskiej (prom. ks. prof. dr hab. S. Longosz, 2008).

29. Zarzeczny Tomasz, Program doskonalenia chrześcijańskiego wedtug Orygenesa w świetle jego homilii o Ewangelii św. Lukasza (prom. ks. prof. dr hab. F. Drączkowski, 2007).

30. Ziemba Anna, Ideat kobiety $w$ wybranych pismach św. Ambrożego $i$ św. Augustyna (prom. ks. prof. dr hab. J. Pałucki, 2008).

31. Zieniewicz Luiza, Ocena antykoncepcji i aborcji jako najstarszych problemów bioetycznych $w$ pismach wczesnochrześcijańskich (prom. ks. prof. dr hab. S. Longosz, 2007).

32. Zubrzycka Katarzyna, Relacje między aniołami i ludźmi $w$ listach św. Hieronima (prom. ks. prof. dr hab. M. Szram, 2008).

\section{B. WYDZIAŁ NAUK HUMANISTYCZNYCH}

\section{Instytut Filologii Klasycznej - Katedra Literatury Wczesnochrześcijańskiej}

$$
\text { Prace magisterskie }
$$

1. Cygan Paulina, Mitologia u Auzoniusza (prom. prof. dr hab. J.G. Malinowska, 2008).

2. Czajkowska Elżbieta, Źródła antyczne a adaptacje filmowe na podstawie „Quo vadis” Henryka Sienkiewicza (prom. prof. dr hab. J.G. Malinowska, 2008).

3. Dykowski Piotr, Motywy antyczne w pismach bpa Romana Andrzejewskiego (prom. ks. prof. dr hab. A. Eckmann).

4. Kątny Łukasz, Tajemnica Ducha Świętego w świetle „De principiis” Orygenesa (prom. ks. prof. dr hab. A. Eckmann, 2008).

5. Michalska Bernadeta, Attyla w świetle pism późnego antyku $i$ wczesnego średniowiecza (prom. ks. prof. dr hab. A. Eckmann, 2008). 
6. Strankowski Marian, Obecność poetów epoki augustowskiej w listach św. Hieronima ze Strydonu (prom. ks. prof. dr hab. A. Eckmann, 2008).

7. Suska Elwira, Virtus w „De civitate Dei” świętego Augustyna (prom. ks. prof. dr hab. A. Eckmann, 2008).

8. Zajączkowska Teresa, Profesor Leokadia Małunowiczówna jako filolog klasyczny (prom. ks. prof. dr hab. A. Eckmann, 2007).

9. Zaremba Stanisław, Znaczenie terminu ,perseverantia” $w$ traktacie „De dono perseverantiae" świętego Augustyna (prom. ks. prof. dr hab. A. Eckmann, 2008).

\section{Instytut Historii Sztuki - Katedra Historii Sztuki Starożytnej i Wezesnochrześcijańskiej}

Prace magisterskie

1. Kiełczewska Aleksandra, Historie biblijne w sztuce żydowskiej późnego anty$k u$ (prom. prof. dr hab. Ryszarda Bulas, 2007).

\section{UNIWERSYTET KARD. STEFANA WYSZYŃSKIEGO W WARSZAWIE}

\section{A. WYDZIAŁ NAUK HISTORYCZNYCH I SPOŁECZNYCH}

\section{Prace habilitacyjne}

1. Ks. Misiarczyk Leszek, Osiem ,logismoi” w pismach Ewagriusza z Pontu, Kraków - Tyniec 2007. Kolokwium 2 VI 2008, recenzenci: ks. prof. dr hab. A.Żurek(PAT), ks. prof. dr hab. M. Szram(KUL), ks. prof. dr hab. J. Naumowicz (UKSW), ks. prof. dr hab. N. Widok (UO).

$$
\text { Prace licencjackie }
$$

1. Babiarz Joanna, Chrześcijańskie spojrzenie na śmierć w świetle wybranych pism Ambrożego z Mediolanu (prom. ks. prof. dr hab. T. Kołosowski, 2007).

2. Brzozowska Krystyna, Życie mnichów w świetle Apoftegmatów Ojców Pustyni i Opowiadań dla Lausosa, Palladiusza (prom. ks. prof. dr hab. T. Kołosowski, 2007).

3. Chmielewska Katarzyna, Obrzęd zawarcia matżeństwa w spotecznościach antycznych a wczesnym chrześcijaństwie (prom. ks. prof. dr hab. T. Kołosowski, 2007).

4. Michalska Katarzyna, Elementy nauki gnostycznej w „Ewangelii Judasza” (prom. ks. prof. dr hab. T. Kołosowski, 2008).

5. Nowosielska Jolanta, Obraz spoleczeństwa u schytku Cesarstwa Zachodniorzymskiego w świetle „De gubernatione Dei” Salwiana z Marsylii (prom. ks. prof. dr hab. T. Kołosowski, 2008).

6. Pietraczuk Agnieszka, Wpływ chrześcijaństwa na rozwój spoleczeństwa rzymskiego i jego kulturę w świetle korespondencji św. Hieronima (prom. ks. prof. dr hab. T. Kołosowski, 2007). 
Prace magisterskie

1. Dziewanowska Alicja, Chrześcijańskie zabytki Stobi w IV-VI wieku po Chr. (prom. dr T. Gołgowski, 2008).

2. Ghenadie Leon, Historiografia archeologii paleochrześcijańskiej w Rumunii po II wojnie światowej (prom. dr T. Gołgowski, 2006).

3. Jakobielska Marta, Topografia Sardes w świetle badań amerykańskich (prom. dr T. Gołgowski, 2008).

4. Jankowski Zbigniew, Starożytna liturgia mszy św. na Wschodzie i Zachodzie: obrzęd - symbolika - teologia. Analiza porównawcza dziet wczesnochrześcijańskich (prom. ks. prof. dr hab. T. Kołosowski, 2007).

5. Karczewska Helena, Czynniki wpływające na wybór pomiędzy dobrem a złem moralnym $w$ życiu człowieka. Studium antropologiczne dziet egzegetycznych $s ́$ w. Hilarego z Poitiers (prom. ks. prof. dr hab. T. Kołosowski, 2007).

6. Kordyasz Tomasz, Armia bizantyjska w VI wieku n. e. na podstawie Strategikonu Maurycjusza (prom. dr T. Gołgowski, 2007).

7. Ks. Paradowski W., Kierownictwo duchowe wedlug Ewagriusza z Pontu (prom. ks. dr L. Misiarczyk, 2007).

8. Kuczyński Miłosz Piotr, Ideał kapłaństwa i jego realizacja $w$ życiu kapłańskim $w$ świetle pism wczesnochrześcijańskich $i$ działalności biskupa Ambrożego z Mediolanu i kardynała Stefana Wyszyńskiego (prom. ks. prof. dr hab. T. Kołosowski, 2008).

9. Marczuk Justyna, Katakumba przy Via Latina w Rzymie - odkrycie, architektura oraz rozwój pogląów na temat jej dekoracji malarskiej (prom. dr T. Gołgowski, 2006).

10. Sapiejewska Joanna, Aniołowie w świetle wybranych pism tacińskich autorów wczesnochrześcijańskich (prom. ks. prof. dr hab. T. Kołosowski, 2008).

11. Solecki Andrzej, Św. Augustyn a Rzym. Studium dziet patrystycznych biskupa $z$ Hippony (prom. ks. prof. dr hab. T. Kołosowski, 2007).

12. Tomaszewska Monika, Feniks i jego symbolika w literaturze starożytnej. Analiza porównawcza wybranych pism klasycznych $i$ wczesnochrześcijańskich (prom. ks. prof. dr hab. T. Kołosowski, 2008).

\section{B. WYDZIAŁ TEOLOGICZNY}

\section{Prace magisterskie}

1. Finc Andrzej, Wplyw woli na wybór między dobrem a złem moralnym $w$ życiu człowieka. Studium antropologiczne dziet egzegetycznych św. Hilarego $z$ Poitiers (prom. ks. prof. dr hab. T. Kołosowski, 2007).

2. Kosmatka Jacek, Wiara, nadzieja i miłość w świetle pism egzegetycznych świętego Hilarego z Poitiers (prom. ks. prof. dr hab. T. Kołosowski, 2008).

3. Malek Michał, Żydzi i judaizm w Listach świętego Hieronima (prom. ks. prof. dr hab. T. Kołosowski, 2008). 
4. Możejko Marcin, Ewagriusz z Pontu jako kierownik życia duchowego (prom. ks. prof. dr hab. T. Kołosowski, 2007).

5. Płonka Dariusz, Kapłaństwo w myśli i posłudze biskupa Jana Chryzostoma i papieża Jana Pawła II (prom. ks. prof. dr hab. T. Kołosowski, 2008).

6. Sumisławski Michał, Ojcostwo w świetle wybranych dziet św. Augustyna (prom. ks. prof. dr hab. T. Kołosowski, 2007).

\section{WYDZIAŁ FILOZOFII CHRZEŚCIJAŃSKIEJ \\ Prace doktorskie}

1. Kochańczyk-Bonińska Karolina, Człowiek jako istota złożona. Antropologia Maksyma Wyznawcy. Obrona 22 X 2008, promotor: prof. dr hab. T. Klimski (UKSW), recenzenci: ks. prof. dr hab. T. Stępień (UKSW), prof. dr hab. A. Kijewska (KUL).

\section{PAPIESKI WYDZIAŁ TEOLOGICZNY (= PWT) W WARSZAWIE Sekcja św. Jana Chrzciciela \\ Prace doktorskie}

1. Ks. Ostrowski Grzegorz Józef, Duchowe aspekty czystości, dziewictwa i bezżeństwa w listach św. Ambrożego. Obrona 29 V 2008, promotor: ks. prof. dr hab. M. Starowieyski (UW), recenzenci: ks. prof. dr hab. S. Longosz (KUL) i ks. prof. dr hab. J. Naumowicz (UKSW).

\section{Prace magisterskie}

1. Andebur Żaneta, Dążenie do doskonałości monastycznej wśród anachoretów egipskich na podstawie „Collationes Patrum” Jana Kasjana (prom. ks. dr I. Pająk MSF).

2. Cichos Piotr, Zjednoczenie wewnętrzne Ducha Świętego i Kościoła analogia stosunku zachodzacego pomiędzy dusza i ciałem człowieka w tradycji patrystycznej Kościoła (prom. ks. dr I. Pająk MSF).

3. Szymańska Marzena, Grzech pierworodny i jego skutki wedtug św. Augustyna (prom. ks. dr I. Pająk MSF).

\section{PAPIESKA AKADEMIA TEOLOGICZNA W KRAKOWIE}

\section{A. WYDZIAŁ TEOLOGICZNY W KRAKOWIE \\ Prace habilitacyjne}

1. O. Kasprzak Dariusz OFMCap, Duszpasterze Vwieku. Studium porównawcze myśli pasterskiej św. Piotra Chryzologa i Salwiana z Marsylii, Kraków 2008. Kolokwium X 2008, recenzenci: ks. prof. dr hab. W. Myszor (UŚ), ks. prof. dr hab. N. Widok (UO), ks. prof. dr hab. H. Pietras (Ignatianum), ks. prof. dr hab. J. Żelazny (PAT). 


\section{Prace doktorskie}

1. Ks. Pochwat Józef MS, Sprawiedliwość i miłosierdzie. Studium „Kazań do ludu” św. Grzegorza z Arles. Promotor: ks. prof. dr hab. E. Staniek (PAT), obrona 20 XII 2007, recenzenci: ks. prof. dr hab. A. Eckmann (KUL) i ks. prof. dr hab. A. Baron (PAT).

2. O. Ościsłowski Krzysztof OSPPE, Ideał chrześcijanina i jego realizacja. Studium pism św. Paulina z Noli. Promotor: ks. prof. dr hab. E. Staniek (PAT), obrona 22 X 2008, recenzenci: o. prof. dr hab. B. Degórski OSPPE (Angelicum, Rzym) i ks. prof. dr hab. J.W. Żelazny (PAT).

3. Ks. Sordyl Krzysztof, Wczesnochrześcijańskie pojęcie Boga. Polemiczne aspekty teologii Nowacjana w „De Trinitate”. Promotor: ks. prof. dr hab. E. Staniek (PAT), obrona 11 VI 2007, recenzenci: o. prof. dr hab. H. Pietras (Ignatianum) i ks. dr hab. A. Baron (PAT).

\section{Prace magisterskie}

1. Ks. Baran Paweł, Nauka św. Jana Chryzostoma o małżénstwie. Tajemnica kapłaństwa. Studium komentarza do Listu do Hebrajczyków Teodoreta z Cyru (prom. ks. prof. dr hab. E. Staniek, 2008).

2. Ks. Błażejowski Tomasz, Wolna wola i wolność. Studium „Wyznañ” św. Augustyna (prom. ks. prof. dr hab. Edward Staniek, 2007).

3. Bolanowski Sławomir, Koncepcja zbawienia w «O zasadach» Orygenesa (prom. ks. dr hab. A. Baron, 2008).

4. Ks. Gałuszka Paweł, Sens pracy fizycznej w życiu mnichów w ujęciu św. Bazylego Wielkiego i św. Augustyna (prom. ks. prof. dr hab. E. Staniek, 2007).

5. Ks. Kasprzak Krzysztof, Pojęcie Boga. Studium „Zachęty do Greków” Klemensa Aleksandryjskiego (prom. ks. prof. dr hab. E. Staniek, 2007).

6. Ks. Kucharczyk Krystian, Misterium nieprawości. Studium „Homilii na Ewangelię" św. Grzegorza Wielkiego (prom. ks. prof. dr hab. E. Staniek, 2007).

7. Ks. Kruszak Marcin, Abraham ojciec wierzacych. Studium Komentarzy do Listu św. Pawła do Rzymian Pelagiusza i Teodoreta z Cyru (prom. ks. prof. dr hab. E. Staniek, 2008).

8. Magdziarz Marcin OP, Koncepcja miłości w Liście o miłości do szambelana Jana Maksyma Wyznawcy (wraz z aneksem zawierającym tekst grecki i polski przekład Listu o miłości Maksyma Wyznawcy) (prom. ks. dr hab. A. Baron, 2008).

9. Ks. Młynarczyk Robert, Osiem błogosławieństw. Studium porównawcze „XV Homilii na Ewangelię św. Mateusza” św. Jana Chryzostoma i traktatu „, Okazaniu Pana na Górze” św. Augustyna (prom. ks. prof. dr hab. E. Staniek, 2007).

10. Ks. Moskal Jacek, Odpowiedzialność duchownych. Studium „, Księgi reguty pasterskiej" Grzegorza Wielkiego (prom. ks. prof. dr hab. E. Staniek, 2007).

11. Ks. Piechowicz Krzysztof, Uwalnianie opętanych. Studium porównawcze „Komentarza do Ewangelii św. Mateusza” św. Hilarego z Poitiers oraz „Homilii na Ewangelię wedtug św. Mateusza” św. Jana Chryzostoma (prom. ks. prof. dr hab. E. Staniek, 2007). 
12. Ks. Popielarczyk Dominik, Troska o duchowieństwo. Studium starożytnych soborów pierwszych pięciu wieków (prom. ks. prof. dr hab. E. Staniek, 2008).

13. Ks. Smalcerz Tomasz, Odpowiedzialność Kościoła za mnichów. Studium kanonów soborów starożytnych (prom. ks. prof. dr hab. E. Staniek, 2008).

14. Ks. Wróbel Piotr Jakub, Troska o duchowieństwo. Studium dokumentów prawnych starożytnych soborów: Konstantynopol II, Konstantynopol III, Nicea II (prom. ks. prof. dr hab. E. Staniek, 2008).

15. Zydroń Dorota, Jezus wobec swej pasji i jej świadkowij wedtug homilii 8188 św. Jana Chryzostoma na Ewangelię św. Mateusza (prom. ks. dr hab.

A. Baron, 2007).

\section{B. ZAMIEJSCOWY WYDZIAŁ TEOLOGICZNY W TARNOWIE}

Prace magisterskie

1. Romański K., ,Uczeń Chrystusa” w świetle „, Komentarza do Ewangelii wedtug Mateusza” Orygenesa (prom. ks. prof. dr hab. A. Żurek, 2007).

2. Żurek Ł., Istotne elementy nauki o jałmuznie w świetle „Homilii na Ewangelię wedtug św. Mateusza” 'św. Jana Chryzostoma (prom. ks. prof. dr hab. A. Żurek, 2007).

\section{UNIWERSYTET ADAMA MICKIEWICZA W POZNANIU (UAM)}

\section{A. WYDZIAE TEOLOGICZNY}

Prace magisterskie

1. Kaczorowski G., Modlitwa nieustanna w świetle patrystycznych tekstów w wyborze rosyjskiej Filokalii Teofana Rekluza (prom. ks. prof. dr hab. L Nieścior OMI, 2008).

2. Kłusek A., Obraz i podobieństwo Boga Trójjedynego w człowieku na podstawie „,De Trinitate” św. Augustyna (prom. ks. prof. dr hab. L. Nieścior OMI, 2008).

3. Konior M., O nie odmawianiu upadtym laski przebaczenia. Traktat „Ad Novatianum" Pseudo-Cypriana. Wstep, tekst, przekład, komentarz (prom. ks. prof. dr hab. L. Nieścior OMI, 2006)

4. Nowosiadły Bogumił, Droga do kontemplacji według Grzegorza z Nazjanzu (prom. ks. dr I. Pająk MSF, 2007).

5. Rurański G., „, Contra Vigilantium” św. Hieronima jako świadectwo sporu na temat niektórych praktyk pobożności chrześcijańskiej. Wstęp, tekst, przekład, komentarz (prom. ks. prof. dr hab. L. Nieścior OMI, 2008).

6. Sadowski P., Staurologia $w$ homiliach i komentarzach Orygenesa do ksiag nowotestamentalnych (prom. ks. prof. dr hab. L. Nieścior OMI, 2005).

7. Wiśniewska Ewa, Droga św. Augustyna do chrześcijaństwa $w$ świetle „,Wyznań” (prom. ks. dr L. Gładyszewski, 2007). 
8. Zaniamonski D., Religijny wymiar egzystencji człowieka ubogiego (pauper) $w$ wybranych pismach św. Augustyna (prom. ks. prof. dr hab. L. Nieścior OMI, 2008).

9. Zieliński M., Dziewictwo i matżeństwo w traktacie „Adversus Iovinianum” św. Hieronima (prom. ks. prof. dr hab. L. Nieścior OMI, 2008).

\section{B. PRYMASOWSKIE WYŻSZE SEMINARIUM DUCHOWNE W GNIEŹNIE}

\section{Prace magisterskie}

1. Andrzejewski Marcin, Chrześcijaństwo a pogaństwo w dialogu „Oktawiusz” Minucjusza Feliksa (prom. ks. prof. dr hab. B. Czyżewski, 2007).

2. Karmoliński Romuald, Przemiana człowieka starego w nowego w ujęciu „, Katechez chrzcielnych” IV wieku (prom. ks. prof. dr hab. B. Czyżewski, 2007).

3. Kowalski Jakub, Praktyczne wskazania przeciwko chciwości bogaczy w ,Historii Nabota” św. Ambrożego z Mediolanu (prom. ks. prof. dr hab. B. Czyżewski, 2007).

4. Prus Krzysztof, Rola modlitwy i pracy w ksztattowaniu wspólnoty mnichów wedtug „,Reguty” św. Benedykta (prom. ks. prof. dr hab. B. Czyżewski, 2007).

5. Rybak Paweł, Eucharystia wżyciu wczesnych wspólnot monastycznych (prom. ks. prof. dr hab. B. Czyżewski, 2008).

6. Sarbinowski Adam, Formowanie nauki Kościoła o chrzcie w środowisku afrykańskim na podstawie Listów (69-75) św. Cypriana (prom. ks. prof. dr hab. B. Czyżewski, 2008).

7. Ks. Świderski Marcin, Rola Eucharystii w procesie chrześcijańskiego wtajemniczenia na podstawie katechez mistagogicznych św. Ambrożego, św. Cyryla Jerozolimskiego i św. Jana Chryzostoma (prom. ks. dr L. Gładyszewski, 2007).

8. Zych Michał, Religijne motywy pielgrzymowania do Ziemi Świętej na podstawie najstarszych opisów pielgrzymek (III-VII w.) (prom. ks. prof. dr hab. B. Czyżewski, 2007).

9. Żebrzowski Krzysztof, Obrona życia nienarodzonych $w$ wybranej literaturze patrystycznej IV i V wieku (prom. ks. prof. dr hab. B. Czyżewski, 2007).

\section{UNIWERSYTET OPOLSKI}

\section{A. WYDZIAŁ TEOLOGICZNY}

\section{Katedra Historii Kościoła i Patrologii}

Prace magisterskie (prom. ks. prof. dr hab. N. Widok)

1. Baca Leszek, Życie mnichów w Lerynie na podstawie pierwszych reguł galijskich (2008).

2. Cisło Damian, Rola muzyki i śpiewu w liturgii czasów Ojców Kościoła (2008).

3. Dulęba Krzysztof, Idat życia monastycznego wedtug Jana Kasjana (2008). 
4. Dzik Ewelina, Problem apostazji prześladowanych chrześcijan oraz ich powrotu do wspólnoty kościelnej w ,Listach” św. Cypriana (2007).

5. Liwowski Jacek, Widowiska epoki klasycznej miejscem zepsucia moralnego w pismach Tertuliana i św. Augustyna (2007).

6. Machulak Leszek, Nauczanie Jana Chryzostoma o miłości bliźniego w „Homiliach do Ewangelii według św. Mateusza” (2008).

7. Misiuda Krzysztof, Problematyka męczeństwa chrześcijan Afryki Pótnocnej w pierwszych wiekach (I-III) (2008).

8. Rajs Grzegorz, Koncepcja kapłaństwa świętego Augustyna (2008).

9. Sadlak Robert, Maryja w nauczaniu świętego Cyryla Aleksandryjskiego (2008).

10. Skolik Andrzej, Trynitarna koncepcja Tertuliana na podstawie „Adversus Praxean" (2008).

11. Wieczorek Tomasz, Mariologia w refleksji teologicznej Efrema Syryjczyka (2007).

12. Zduński Sławomir Mateusz OSB, Świat i człowiek w początku (en arche). Kosmologia i antropologia Orygenesa na podstawie jego „,Pierwszej homilii do Księgi Rodzaju”(2007).

\section{UNIWERSYTET ŚLĄSKI W KATOWICACH}

\section{A. WYDZIAŁ TEOLOGICZNY}

Prace licencjackie

1. Ks. Kamczyk Wojciech, Drugie matżeństwo wedtug św. Augustyna (prom. ks. prof. dr hab. W. Myszor, 2007).

\section{Prace magisterskie}

1. Bałuszyńska Barbara, Bliblijny opis stworzenia i upadku w interpretacji wybranych Ojców przednicejskich (prom. ks. prof. dr hab. J. Słomka, 2007).

2. Cieśla Marcin, Kult św. Marcina z Tours w „Historii Franków” Grzegorza $z$ Tours (prom. ks. prof. dr hab. W. Myszor, 2008).

3. Domagała Iwona, Symbolika mistyczna $w$ pismach Mechtyldy z Magdeburga (prom. ks. prof. dr hab. W. Myszor, 2008).

4. Gawliczek Krzysztof, Nauka o demonach Ewagriusza z Pontu (prom. ks. prof. dr hab. J. Słomka, 2007).

5. Kałuziak Michał, Historia i historiozofia $w$ poezji Prudencjusza na przykładzie „, Contra Symmachum” (prom. ks. prof. dr hab. W. Myszor, 2008).

6. Kołodziejczyk Michał, Tradycja synoptyczna w utworze „Myśl naszej Wielkiej Mocy” (Nag Hammadi VI, 4) (prom. ks. prof. dr hab. W. Myszor, 2007).

7. Kuś Marcin, „Otwarte pytania” w pismach teologicznych Orygenesa (prom. ks. prof. dr hab. W. Myszor, 2007).

8. Lach Ludmiła, Symbolika duszy jako ,kobiety” w pismach egzegetycznych Orygenesa (prom. ks. prof. dr hab. W. Myszor, 2007). 
9. Moj Marcin, Symbolika ,studni” w pismach egzegetycznych Orygenesa (prom. ks. prof. dr hab. W. Myszor, 2008).

10. Oko Jan, Matzeństwo i rodzina $w$ świetle postanowień synodów czasów Merowingów (prom. ks. prof. dr hab. W. Myszor, 2008).

11. Piekło Piotr, Pojęcie „osoba” w „Mowach” Grzegorza z Nazjanzu (prom. ks. prof. dr hab. J. Słomka, 2008).

12. Rumińska Anna, Biskup w Kościele i społeczeństwie Galii merowińskiej wedlug „Historii Franków” Grzegorza z Tours (prom. ks. prof. dr hab. W. Myszor, 2008).

13. Waręda Marek, Symbolika krzyża w gnostycyzmie (prom. ks. prof. dr hab. W. Myszor, 2008).

\section{UNIWERSYTET MIKOLAJA KOPERNIKA W TORUNIU}

\section{A. WYDZIAE TEOLOGICZNY}

Prace magisterskie (prom. ks. dr T. Kaczmarek)

1. Felczykowski Paweł, Św. Augustyn, De disciplina christiana. Wstęp, komentarz, thumaczenie (2007).

2. Ks. Recki Tomasz Kościót jako mistyczne Ciało Chryzsstusa w świetle „Objaśnień do Psalmów” św. Augustyna (2008).

3. Ks. Skarzyński Łukasz, Wrażliwość pasterska św. Ambrożego z Mediolanu na problemy społeczne $w$ świetle pism „, O Nabocie” $i$ „, O Tobiaszu” (2008).

4. Ks. Sobociński Paweł, Postaci, wydarzenia i motywy biblijne jako figury Kościoła w „Enarrationes in Psalmos” św. Augustyna (2008).

5. Ks. Tomczak Sebastian, Symbol Apostolski w życiu starożytnego Kościoła (2007).

\section{UNIWERSYTET GDAŃSKI}

\section{A. WYDZIAŁ HISTORYCZNY}

\section{Zakład Historii Starożytnej \\ Prace doktorskie (1998-2008)}

1. Gajewski Wojciech, Struktura organizacyjna Kościoła do połowy II wieku w Cesarstwie Rzymskim. Promotor prof. dr hab. J. Iluk (UG), obrona 6 VII 1998, recenzenci: prof. dr hab. M. Filipiak (UMCS) i prof. dr hab. W. Pałubicki (UG).

2. Górka Bogusław, Basileia a Ekklesia w koncepcji Mateusza. Promotor. prof. dr hab. J. Iluk (UG), obrona 24 VI 1996, recenzenci: ks. prof. dr hab. H. Pietras (PWT Warszawa) i prof. dr hab. W. Pałubicki (UG).

3. Krzykowski Leszek, Metody prowadzenia sporów wewnatrzkościelnych w IV $i$ w 1. pot. V wieku w pracach niektórych antycznych historyków Kościoła. Promotor prof. dr hab. J. Iluk (UG), obrona 7 VI 2006, recenzenci: ks. prof. dr 
hab. A. Eckmann (KUL) i prof. dr hab. J. Jundziłł (WSP Bydgoszcz).

4. Michalak Aleksander Roman, Ideologia świętej wojny w świetle ruchów rewolucyjnych w Palestynie w poczatkach chrześcijaństwa (4 r. p.n.e. - 73 r. n.e.). Promotor prof. dr hab. J. Iluk (UG), obrona 9 V 2006, recenzenci: prof. dr hab. L. Mrozewicz (UAM) i ks. prof. dr hab. H. Pietras (WSFP, Ignatianum).

5. Milewski Ireneusz, Pieniądz w pismach greckich Ojców Kościoła IV wieku (na przykładzie pism Kapadockich Ojców Kościoła i Jana Chryzostoma). Promotor prof. dr hab. J. Iluk (UG), obrona 25 V 1998, recenzenci: ks. prof. dr hab. W. Ceran (UŁ) i prof. dr hab. M. Salamon (UJ).

6. Ożóg Monika, Stosunek późnoantycznych chrześcijan do rzymsko-hellenistycznych świątyń i posagów bóstw. Promotor: prof. dr hab. J. Iluk (UG), obrona 21 V 2008, recenzenci: prof dr. hab. U. Mazurczak (KUL) i prof. dr hab. H. Pietras (Ignatianum).

7. Pająkowska Anna, Cesarz Julian Apostata w świadectwach historyka Ammiana Marcelina i teologa Grzegorza z Nazjanzu. Promotor: prof. dr hab. J. Iluk (UG), obrona 16 X 2007, recenzenci: prof. dr hab. W. Ceran (UŁ) i prof. dr hab. L. Mrozewicz (UAM).

\section{Prace magisterskie (1994-2008)}

1. Bednarz Jolanta, Cesarstwo Rzymskie w okresie panowania Konstantyna Wielkiego i jego synów w świetle „Historii Kościoła” Sokratesa Scholastyka i Hermiasza Sozomena (prom. prof. dr hab. J. Iluk, 1994).

2. Beling Justyna, Kontrowersje wokót Orygenesa - pomiędzy kulturą antyczna a chrześcijaństwem (prom. prof. dr hab. J. Iluk, 1999).

3. Brodek Agnieszka, Kluczowe aspekty zjawiska donatyzmu w Afryce Pótnocnej (prom. prof. dr hab. J. Iluk, 2001).

4. Gajewski Wojciech, Wpływ religii żydowskiej na teologie i strukture organizacyjna gmin wczesnochrześcijańskich w Cesarstwie Rzymskim w latach 130135 (prom. prof. dr hab. J. Iluk, 1991).

5. Grenc Ewa, Qumran - próba identyfikacji osiedla oraz przedstawienie stanu badań (prom. prof. dr hab. J. Iluk, 1998).

6. Herzberg Arkadiusz, Tertulian. Społeczeństwo i Kościót w opinii afrykańskiego Apologety (prom. prof. dr hab. J. Iluk, 2004).

7. Hirsz Anna, Rodzina we wczesnym chrześcijaństwie w świetle pism Klemensa Aleksandryjskiego, Tertuliana i Orygenesa (prom. dr W. Gajewski, 2008).

8. Jankowska Ewa, Dziewice w stużbie Bożej w początkach chrześcijaństwa IV wiek (prom. prof. dr hab. J. Iluk, 1998).

9. Jeszke Celina, Biblia $w$ wybranych obrazach Petera Paula Rubensa (prom. prof. dr hab. J. Iluk, 1998).

10. Kapela Tomasz, Wspólnota chrześcijańska w starożytności rzymskiej (prom. prof. dr hab. J. Iluk, 1997).

11. Korejba Katarzyna, Kościót IV stulecia w prawie rzymskim (prom. prof. dr hab. J. Iluk, 1999).

12. Krzykowski Leszek, Św. Ambroży i św. Hieronim wobec społeczno-politycznych 
problemów Cesarstwa Rzymskiego w IV wieku (prom. prof. dr hab. J. Iluk, 1994).

13. Lemańczyk Dorota, Romanitas w rodzącym się państwie chrześcijańskim (prom. prof. dr hab. J. Iluk, 1997).

14. Lizak Iwona, Etyka i ideały społeczne chrześcijaństwa $w$ realiach państwa rzymskiego epoki cesarstwa (prom. prof. dr hab. J. Iluk, 1991).

15. Maciejewska Jolanta, Kobieta w kręgu moralistyki chrześcijańskiej i późno antycznego prawa (prom. prof. dr hab. J. Iluk, 1995).

16. Mierkułów Anna, Życie codzienne $w$ Antiochii $w$ świetle Komentarza do Ewangelii św. Mateusza autorstwa Jana Chryzostoma (dr I. Milewski, 2004).

17. Milewski Ireneusz, Działalność dobroczynna Kościoła w IV i V wieku (prom. prof. dr hab. J. Iluk, 1994).

18. Napierała Magdalena, Magia w nauce św. Augustyna (prom. prof. dr hab. J. Iluk, 1999).

19. Ks. Nestoruk Krzysztof, Życie codzienne w miastach rzymskiej Afryki w świetle pism Tertuliana (dr I. Milewski, 2004).

20. Odebralski Robert, Arianizm. Konfesja dzielaca religię i narody (prom. prof. dr hab. J. Iluk, 1998).

21. Polaczuk Piotr, Prymat Rzymu w świetle twórczości Klemensa Rzymskiego i Ireneusza z Lyonu oraz kontrowersji wielkanocnej (prom. dr W. Gajewski, 2007).

22. Ropiak Piotr, Chrześcijańska paideia (prom. prof. dr hab. J. Iluk, 2001).

23. Ruczyńska Joanna, Cesarze, wspótrzadcy i uzurpatorzy późnego cesarstwa rzymskiego w świetle „Dziejów Rzymskich” Ammianusa Marcellinusa (prom. dr W. Gajewski, 2008).

24. Sypion Waldemar, Religijność Rzymian w okresie panowania Augusta (prom. dr W. Gajewski, 2007).

25. Tenderenda Jacek, Dynastia Konstantyńska. Restauracja państwa (prom. prof. dr hab. J. Iluk, 1998).

26. Tomaszewicz Izabela, Augustyńska wizja państwa w świetle „De civitate Dei” (prom. prof. dr hab. J. Iluk, 1996).

\section{UNIWERSYTET SZCZECIŃSKI}

\section{A. WYDZIAŁ TEOLOGICZNY}

\section{Instytut Teologiczny w Gorzowie}

Prace magisterskie

(prom. ks. prof. dr hab. L. Nieścior OMI)

1. Kołodziej T., Program życia chrześcijańskiego w świecie wedtug „,Homilii na Ewangelie" św. Grzegorza Wielkiego (2005).

2. Korasiak B., Usprawiedliwienie z wiary i uczynków na podstawie dziet nt. Listu św. Pawła do Rzymian św. Jana Chryzostoma i Pelagiusza (2005).

3. Król-Nowicka S., Etos świeckiego chrześcijanina w „Homiliach św. Jana Chryzostoma na Ewangelię wg św. Mateusza” (2005). 
4. Rösler H., ,,Praktike” $i$,, gnostike” jako podstawowe stopnie życia duchowego w ujęciu Ewagriusza z Pontu (2005).

5. Zając L., Zasady moralności chrześcijańskiej w piśmie Orygenesa „Przeciw Celsusowi” (2005).

\section{X.UNIWERSYTET MARII CURIE-SKLODOWSKIEJ W LUBLINIE}

\section{A. WYDZIAŁ HUMANISTYCZNY}

\section{Zakład Historii Starożytnej}

Prace magisterskie

(prom. dr H. Kowalski)

1. Kędzierski Przemysław, Historia magistra vitae? Narodziny chrześcijaństwa w podrecznikach akademickich historii epoki PRL (2007).

\section{WYŻSZE SEMINARIUM DUCHOWNE W LODZI}

(prom. ks. dr hab. J. Słomka)

Prace magisterskie (bronione na UKSW)

1. Adamczewski Łukasz, Życie moralne chrześcijanina wedtug Grzegorza Wielkiego na podstawie ,Homilii na Ewangelie” (2007).

2. Lewińska Katarzyna, Rola modlitwy w życiu mnicha wedtug Jana Kasjana (2007)

3. Pawlata Małgorzata, Postać Chrystusa w Ewangelii Prawdy (2008).

4. Woźny Łukasz, Ocena batwochwalstwa u Tertuliana (2008).

\section{INSTYTUT TEOLOGICZNY (WYŻSZE SEMINARIUM DUCHOWNE W RADOMIU)}

(prom. ks. dr P. Turzyński)

Prace magisterskie

(bronione w PWT w Warszawie: 2001-2008)

1. Adamczyk Marek, Nauka św. Ambrożego o Kościele na podstawie „, Wykładu do Ewangelii wedtug św. Łukasza” (2004).

2. Biel Iwona, Miłość w komentarzach do ksiag Starego Testamentu Orygenesa (2005).

3. Bruzda Krystian, Nauka o aniołach $w$,,De principiis ”Orygenesa (2005).

4. Chmielewska Teresa, Dobro i zło w ,Dialogach” św. Augustyna (2007).

5. Dk. Cieślik Marcin, Droga doskonalenia duchowego w pismach ascetycznych św. Grzegorza z Nyssy (2007).

6. Dk. Czupryński Arkadiusz, Ideat mnicha w ,, Collationes Patrum” św. Jana Kasjana (2002).

7. Dyoniziak Małgorzata, Modlitwa w ,Komentarzu do Psalmów ”św. Augustyna (2006). 
8. Gąsiorek Aneta, Biblia w tradycji monastycznej pierwszych wieków (2007).

9. Guzińska Izabela, Mitość w „Collationes Patrum” św. Jana Kasjana (2005).

10. Jakubiak Beata, Wolność $w$,Homiliach na ewangelie i pierwszy list świętego Jana" świętego Augustyna (2006).

11. Dk. Janczyk Ernest, Miłość w pismach ascetycznych św. Bazylego Wielkiego (2002).

12. Jaśkiewicz Konrad, Zagadnienia biblijne w listach św. Hieronima (2004).

13. Kacprzak Beata, Teologia męczeństwa w pismach Euzebiusza z Cezarei (2004).

14. Kaczmarczyk Barbara, Pokój serca w tradycji monastycznej pierwszych wieków (2008).

15. Kaleta Paweł, Radość w ,Wyznaniach” św. Augustyna (2004).

16. S. Kalinowska Magdalena, Troska pasterska o kobiety na podstawie „Listów” św. Hieronima (2006).

17. Kania Krzysztof, Ideat pasterza wedtug św. Jana Chryzostoma (2004).

18. Kochańska Katarzyna, Rzeczy ostateczne w De principiis Orygenesa (2005).

19. Kozłowska Aneta, Kobieta w pismach św. Augustyna o matżeństwie i dziewictwie (2006).

20. Księżopolski Krzysztof, Smutek w pismach Ewagriusza z Pontu (2007).

21. Łucka Jolanta, Nauka o Jezusie Chrystusie w kazaniach św. Leona Wielkiego (2004).

22. Łukawska Violetta, Łaska w ,Wyznaniach” św. Augustyna (2008).

23. Misiura Elżbieta S., Pragnienie Boga w ,Wyznaniach” $i$ „Dialogach” św. Augustyna (2003).

24. Monkosa Iwona, Maryja w „Komentarzu do ewangelii św. Lukasza ”’́w. Ambrożego (2007).

25. Neska Kinga, Modlitwa we wschodniej tradycji monastycznej pierwszych wieków chrześcijaństwa (2007).

26. Dk. Okoń Marek, Ideat kapłana w „De officiis ministrorum” św. Ambrożego (2007).

27. Pałgan Barbara, Droga doskonalenia chrześcijańskiego $w$ nauce św. Doroteusza z Gazy (2004).

28. Pielas Małgorzata, Chwała Boża w „Enarrationes in Psalmos” św. Augustyna (2007).

29. Róg Marcin, Koncepcja życia monastycznego w „Listach” św. Hieronima (2006).

30. Ks. Sala Zenon, Pragnienie Boga w „Homiliach na Ewangelie” św. Grzegorza Wielkiego (2002).

31. Spiżewski Damian, Ideat mnicha w monastycyzmie egipskim III i IV wieku (2004).

32. Ks. Stępień Ryszard, Ojcostwo duchowe w apoftegmatach Ojców pustyni (2001). 
33. Surowiec Agnieszka, Nauka o niebie w „O państwie Bożym ”'św. Augustyna (2006).

34. Dk. Szwabowicz Józef, Miłość w kazaniach św. Cezarego z Arles (2002).

35. Dk. Ślęzak Łukasz, Elementy teologii w poezji św. Efrema (2008).

36. Tomczyk Artur, Drogi uświęcania człowieka w ,Regule” i tradycji benedyktyńskiej (2006).

37. Zieliński Bartłomiej, Cierpienie w „Homiliach na ewangelie świętego Jana” świętego Augustyna (2005).

38. Dk. Zieliński Jarosław, Rzeczy ostateczne w „,De civitate Dei ” św. Augustyna (2008).

\title{
XIII. WYŻSZE SEMINARIUM DUCHOWNE W PARADYŻU
}

(prom. ks. prof. dr hab. L. Nieścior OMI)

Prace magisterskie

1. Kubala M., Pamflet polemiczny św. Hieronima „Altercatio luciferiani et orthodoxi" jako świadectwo sporu z lucyferianami o miejscu grzesznika i błędnowiercy w Kościele. Wstęp, tekst, przekład, komentarz (bronione na Wydziale Teologicznym Uniwersytetu Szczecińskiego, 2006).

\section{STUDIUM TEOLOGII WE WLOCŁAWKU}

(bronione w PWT Warszawa - Sekcja św. Jana Chrzciciela)

$$
\text { Prace magisterskie }
$$

1. Elzanowska Edyta, Portrety chrześcijan z dwóch pierwszych stuleci Kościoła (prom. ks. dr T. Kaczmarek, 2008).

2. Sienkiewicz Barbara, Godność matżeństwa chrześcijańskiego w świetle pism polemicznych św. Augustyna (prom. ks. dr T. Kaczmarek, 2008).

3. Wojciechowska Małgorzata, Kulturotwórcza obecność chrześcijan w świecie antycznym w świetle literatury patrystycznej (prom. ks. dr T. Kaczmarek, 2008).

\section{KOLEGIUM FILOZOFICZNO-TEOLOGICZNE OJCÓW DOMINIKANÓW W KRAKOWIE}

\author{
Prace magisterskie \\ (bronione w UJ, Kraków)
}

1. Kłos Michał OP, Struktura duszy w tradycji starozytnej i wczesnochrześcijańskiej (prom. dr J. Kiełbasa, 2007).

2. Bejczi Tibor OP, Kim jest człowiek w świetle nauki św. Augustyna i św. Tomasza z Akwinu (prom. dr J. Kiełbasa, 2007). 


\title{
XVI. UCZELNIE ZAGRANICZNE
}

\author{
Prace doktorskie
}

1. O. Pancerz Roland Marcin, Christi anima apud Didymum Caecum, Università Pontificia Salesiana, Facoltà di Lettere Cristiane et Classiche, Roma. Promotor: prof. prof. E. Dal Covolo SDB, obrona 27 IX 2007, recenzenci: prof. E. Prinzivalli i prof. O. Pasquato.

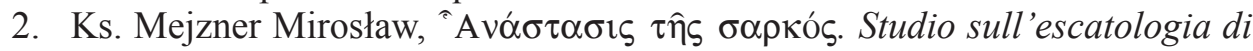
Metodio di Olimpo, Pontificia Universitas Lateranensis. Institutum Patristicum Augustinianum, Romae. Promotor: prof. E. Prinzivalli, obrona 2007, recenzenci: prof. M. Simonetti i prof. V. Grossi OSA.

zebrał i opracował ks. Stanisław Longosz - Lublin, KUL 